Fiorence Surya, Gregorius Genep Sukendro: Komunikasi Pemasaran The Watch Co dalam Meningkatkan Brand Awareness di Sosial Media

\title{
Komunikasi Pemasaran The Watch Co dalam Meningkatkan Brand Awareness di Sosial Media
}

\author{
Fiorence Surya, Gregorius Genep Sukendro \\ fiorencesurya@gmail.com, geneps@fikom.untar.ac.id \\ Fakultas Ilmu Komunikasi Universitas Tarumanagara
}

\begin{abstract}
The development of increasingly modern technology most companies use sosial media in creasing brand awareness, because in sosial media the community will be easier to access and obtain information about a product. This research is qualitative descriptive with data collection techniques using observation and interviews. The theory used from this study uses the theory of communication, mass communication, new media, marketing communications, brand awareness, from the results of this study it can be concluded that the role of social media, especially Instagram and Facebook has a considerable influence in increasing brand awareness.
\end{abstract}

Key words: marketing communication, brand awareness, social media

\begin{abstract}
Abstrak
Berkembangnya teknologi yang semakin modern, sebagian besar perusahaan menggunakan sosial media dalam melakukan komunikasi pemasarannya. Tujuan dari penelitian ini adalah untuk mengetahui media sosial dalam meningkatkan Brand Awareness, karena di dalam sosial media masyarakat akan lebih mudah untuk mengakses dan mendapatkan informasi mengenai suatu produk dan nantinya konsumen mempunyai sebuah keputusan terhadap produk tersebut. Penelitian ini bersifat kualitatif deskriptif dengan teknik pengumpulan data menggunakan cara observasi dan wawancara yang mendalam. Konsep yang digunakan dari penelitian ini menggunakan teori komunikasi, komunikasi massa, media baru, komunikasi pemasaran, brand awareness. Hasil penelitian ini dapat disimpulkan bahwa peranan sosial media khususnya di instagram dan Facebook mempunyai pengaruh yang cukup besar dalam meningkatkan brand awareness.
\end{abstract}

Kata kunci : Komunikasi permasaran, brand awareness, sosial media

\section{Pendahuluan}

Seiring dengan pertumbuhan ekonomi di Indonesia yang semakin meningkat, maka semakin banyak pula perusahaan yang didirikan, hal ini mengakibatkan persaingan semakin banyak dan ketat. Salah satunya perusahaan yang bergerak di bidang aksesoris seperti jam tangan, pada era globalisasi ini trend jam tangan di Indonesia terus meningkat karena Indonesia terus mengimpor 2,4 juta kilogram jam tangan dalam 6 bulan terakhir. Jika dinilai dalam nilai uang, semua itu mencapai 41 juta dolar AS atau setara dengan 546,3 miliar rupiah dan jenis yang paling banyak di impor adalah jenis jam tangan digital (Badan Pusat Statistik, 2017).

The Watch Co didirikan pada tahun 2013, telah membangun fondasinya pada kualitas yang baik dan desain yang inovatif. Dengan melihat adanya peluang akhirnya The Watch Co yang berada di bawah naungan PT. Kami Gawi Berjaya memutuskan untuk menjadi distributor dan importir kebutuhan fashion pria maupun 
wanita yang berfokus pada jam tangan original diantaranya bermerek Daniel Wellington, Olivia Burton, Komono, Timex, Braun, Casio, dan William L. Tidak hanya jam tangan The Watch Co juga menjual aksesoris lainnya seperti strap jam tangan, gelang, kacamata, jaket, tas, majalah yang dapat dibeli secara online maupun offline (sumber: thewatch.co)

Di bagian struktur organisasi perusahaan, komunikasi pemasaran bisa dikatakan cukup penting dalam sebuah kegiatan usaha yang dibutuhkan untuk membuat perencanaan, menentukan suatu harga, mengiklankan atau membujuk dan mendistribusikan barang ataupun jasa yang dapat memuaskan kebutuhan kepada pembeli maupun calon pembeli. Komunikasi pemasaran merupakan kegiatan komunikasi yang dilakukan oleh pembeli dan penjual yang sangat membantu dalam pengambilan keputusan di bidang pemasaran ataupun penjualan, serta mengarahkan pertukaran agar lebih memuaskan dengan cara menyadarkan semua pihak untuk berbuat lebih baik. Di dalam komunikasi pemasaran, membangun kepercayaan di suatu perusahaan bisa dilakukan melalui efektivitas pesan yang digulirkan dengan cara menentukan target pasar .Untuk menentukan target pasar, salah satu masalah pokok yang menjadi kendala dalam pemasaran adalah banyaknya persaingan didalam pasar itu sendiri dalam memenuhi kebutuhan masyarakat (sumber: repository.fisipuntirta.ac.id).

Perkembangnya jaman pada saat ini teknologi infomasi semakin pesat dan berkembang dengan adanya internet, semua orang bisa mendapatkan dan mencari informasi ke seluruh penjuru dunia dengan secara luas mengakses informasi dengan adanya internet. Begitu pula dengan sosial media yang dapat menyebarkan informasi ke seluruh masyarakat. Sosial media memungkinkan para pelaku pasar baik targetnya konsumen dan calon konsumennya untuk dapat berkomunikasi dengan sesamanya, pelanggan, dan calon pelanggan. Sosial media memberikan identitas kepada brand atau merek yang dipasarkan dan membantu untuk menyebarkan dan memberikan pesan dengan cara yang santai dan komunikatif (sumber: jurnal.usu.ac.id).

Perusahaan mencoba untuk mendapatkan konsumen baru atau calon konsumennya dengan cara mempromosikan produknya untuk membangun brand awareness dari produk The watch co, maka dari itu brand awarness merupakan salah satu aspek yang cukup penting pada tahap awal dari proses pembelian suatu produk karena jika konsumen tidak sadar dengan keberadaan dari suatu produk maka akan sulit untuk memutuskan memilih suatu produk (sumber: digilib.uinsby.ac.id).

The Watch Co mengiklankan produknya dengan berbagai macam cara seperti iklan dari majalah, banner, dan media sosial. Di media sosial salah satunya instagram The Watch Co selalu menampilkan produknya dengan gaya yang aesthetic yang bertujuan untuk meningkatkan kesadaran dari suatu merek. Konsumen yang merujuk pada usia 17-35 tahun. melalui sosial media ini dapat memudahkan pelanggan baru yang belum mengetahui untuk dapat mengetahui informasi dari suatu produk yang sedang berkembang di pasaran.

\section{Metode Penelitian}

Penelitian ini menggunakan pendekatan penelitian kualitatif dengan memiliki dasar deskriptif guna memahami suatu fenomena dengan lebih mendalam dan berusaha menerangkan fenomena sosial tertentu. Penelitian kualitatif merupakan salah satu metode penelitian yang bersifat deskriptif dan cenderung mencari sebuah makna dari data yang didapatkan dari hasil sebuah penelitian. Metode ini biasanya 
Fiorence Surya, Gregorius Genep Sukendro: Komunikasi Pemasaran The Watch Co dalam Meningkatkan Brand Awareness di Sosial Media

digunakan seseorang ketika akan meneliti terkait dengan masalah sosial dan budaya. Menurut Sugiyono (2014) mengatakan bahwa metode penelitian kualitatif sering disebut metode penelitian naturalistik karena penelitiannya dilakukan pada kondisi yang masih alamiah (natural setting).

Seiring dengan perkembangan yang semakin modern, penelitian kualitatif kemudian terbagi menjadi beberapa macam jenis pendekatan. Pendekatan yang diartikan adalah sesuatu pendekatan yang digunakana untuk lebih memudahkan peneliti untuk mengkaji sebuah masalah yang sedang diteliti membagi jenis pendekatan dalam penelitian kualitatif menjadi 5 bagian, yakni Fenomenologi, Etnografi, Studi Kasus, Teori Grounded, dan Naratif. (http://penalaranunm.org/metode-penelitian-kualitatif-dengan-jenis-pendekatan-studi-kasus/). Yang dimaksud subyek penelitian adalah orang, tempat, atau benda yang diamati sebagai sasaran ( Kamus Bahasa Indonesia, 1989:862).

Penelitian ini, objek dari hasil penelitian yang berjudul "Komunikasi Pemasaran The Watch Co dalam membangun Brand Awareness dalam sosial media adalah akun media sosial Instgram dan Facebook sebagai media promosinya.

\section{Hasil Temuan dan Diskusi}

Dari berbagai jenis iklan di The Watch Co jenis iklan produk. Hal ini dikarenakan didalam menjual jam tangan selain mencantumkan harga pada iklan, perlu juga untuk mencantumkan deskripsi atau gambaran tentang fitur-fitur, baik itu berupa bentuk, warna dan kegunaan dari jam tersebut, sehingga membuat konsumen atau calon konsumen mempunyai gambaran tentang produk yang dijual dan terus meningkatkan kesadaran akan hadirnya dari merek tersebut.

Walaupun The Watch Co berdiri di zaman yang modern, The Watch Co tidak menggunakan iklan buttons dan pop-up ads didalam memasarkan produknya, melainkan berkerjasama dengan para artis ataupun blogger, karena The Watch Co merasa orang Indonesia jika tidak memiliki keperluan dan kepentingan untuk membeli jam tangan, mereka tidak akan mengunjungi situs-situs The Watch Co. Hal ini menyebabkan iklan dipasang The Watch Co akan sia-sia karena tidak banyak orang yang melihat, apabila bekerjasama dengan beberapa para artis The Watch Co akan lebih focus untuk menargetkan pasar mana yang ingin dituju. Contoh implementasi yang dilakukan The Watch Co dalam menjalankan iklan majalah yang bekerjasama dengan majalah Bazaar, Best Life, Cleo, Grazia, Her World, Juice Magazine, Maxim, Mens Folio, Nylon Magazine, News Living, Style \& Décor, dan Trax. Hal terpenting dari isi iklan majalah ini adalah kejelasan produk jam tangan yang dijual oleh The Watch Co, karena kelebihan dari iklan majalah adalah konsumen atau calon konsumen dapat melihat kualitas iklan secara lebih visual.

Media sosial adalah sebuah media online dimana para user bisa mendapatkan dengan mudah atau praktis agar dapat mengikuti dalam artian seseorang akan dengan gampang membagikan sebuah informasi, menciptakan atau memberikan isi yang ingin disampaikan kepada orang lain member komentar terhadap masukkan yang diterimanya (Ardianto 2011:49). Keunggulan dari sosial media dalam menggalang opini di dunia maya mulai diperhitungkan oleh banyak pihak, tidak mengherankan jika suatu merek perusahaandapat dicitrakan secara baik (Ardianto 2011:33).

Media sosial merupakan salah satu komponen yang berada di dalam dunia teknologi. Sebagaian besar orang di dunia sekarang memiliki akun media sosial, Contoh sosial media yang digunakan oleh The Watch Co adalah Instagram dan 
Facebook. Instagram membantu The Watch Co dalam menjangkau target pasar yang belum dapat dijangkau oleh pihaknya. Selain mengandalkan Instastory dan mengunggah foto, The Watch Co melakukan endorse dengan Bloggers, selebgram dan artis untuk memperkenalkan produknya. Endorse ini berbentuk pemberian produk dari The Watch Co yang nantinya para blogger dan artis akan mengunggah foto dirinya bersama produk dari The Watch Co yang sudah ditentukan dan disepakati. Berkat eksistensi dari blogger dan artis ini perusahaan akan lebih mudah untuk menangkap dan masuk ke pasar millennials karena anak millenials biasanya mengikuti gaya dari idolanya.

\section{Simpulan}

Beberapa kesimpulan yang dapat disampaikan oleh penulis berdasarkan hasil obervasi dan wawancara yang dilakukan adalah mempromosikan produk-produk The Watch Co dengan internet maupun media sosial seperti website, Facebook, Instagram yang bekerjasama dengan para artis dan blogger untuk mencakup secara luas dan sesuai dengan target pasarnya, serta memudahkan perusahaan untuk memperkenalkan produk-produk baru dari The Watch Co kepada konsumen dan calon konsumennya. Manfaat adanya promosi dengan menggunakan media sosial untuk membantu The Watch Co menciptakan brand awareness dan memberikan gambaran atau deskripsi mengenai produk jam tangan yang diperjualkan, sehingga menciptakan penjualan jangka panjang, menciptakan penjualan secara langsung pada The Watch Co. Saat ini The Watch Co secara khusus menggunakan media sosial untuk menargetkan generasi millennials di dalam memasarkan produk jamnya, hal ini dikarenakan kategori pasar ini dirasa cukup sulit dijangkau jika hanya mengandalkan toko offline.

Tidak hanya dalam internet dan media sosial tetapi TheWatch Co juga mempromosikan produknya dengan membuat banner dan ditempatkan pada lokasi yang strategis agar konsumen dan calon konsumen dapat melihat produk The Watch Co apabila perusahaan memperkenalkan produk baru ataupun ada promo potongan harga, dan berbagai macam majalah yang tujuannya untuk memberitahukan informasi dan mengingatkan.

\section{Ucapan Terima kasih}

Hasil skripsi yang telah diselesaikan yang dilakukan oleh penulis mengenai Komunikasi Pemasaran The Watch Co dalam Membangun Brand Awareness di Sosial Media. Guna memenuhi salah satu persyaratan untuk memperoleh gelar strata satu program Ilmu Komunikasi Universitas Tarumanagara. Penulis ingin mengucapkan terima kasih kepad Ibu Dr. Riris Loisa,M.Si selaku Dekan Fakultas Ilmu Komunikasi Universitas Tarumanagara dan Bapak G. Genep Sukendro, S.Sos,M.Si selaku Dosen pembimbing materi dan teknik penulisan laporn skripsi yang telah meluangkan waktunya untuk memberikan bimbingan skripsi bagi penulis. Juga berterima kasih kepada narasumber yang telah bersedia meluangkan waktunya untuk bisa diwawancara, semoga penelitian skripsi yang telah disusun ini dapat memberikan manfaat bagi pembaca dan perkembangan Ilmu Komunikasi, khususnya di Fakultas Ilmu Komunikasi Universitas Tarumanagara. 
Fiorence Surya, Gregorius Genep Sukendro: Komunikasi Pemasaran The Watch Co dalam Meningkatkan Brand Awareness di Sosial Media

\section{Daftar Pustaka}

Aaker, David A (1997). Manajemen Ekuitas Merek. Jakarta:Penerbit Mitra Utama.

A.M, Morissan. (2010). Periklanan Komunikasi Pemasaran Terpadu, Jakarta: Penerbit Kencana.

Amirin, Tatang M, (1986). Menyusun Rencana Penelitian, Jakarta:Rajawali

Basu, Swatha. (1999). Saluran Pemasaran. Cetakan keenam, (BPEF-Yogyakarta)

Basu, Swastha dan Irawan. (2001). Manajemen Pemasaran Modern. Yogyakarta: Liberty

Badan Pusat Statistik,(2017).

Bungin, Burhan. (2007). Penelitian Kualitatif: Komunikasi, Ekonomi, Kebijakan Publik dan Ilmu Sosial lainnya. Jakarta: Putra Grafika.

Durianto, Darmadi, dkk (2001). Strategi Menaklukkan Pasar. Jakarta : PT. Gramedia Pustaka Utama

Effendy, Uchjana Onong. (2004). Ilmu Komunikasi Teori dan Praktek. Bandung: PT. Remaja Rosdakarya.

Kamus Bahasa Indonesia, Subyek Penelitian, 1989:862

Kotler, Philip (2002), Manajemen Pemasaran, Edisi Millenium, Jilid 2, PT Prenhallindo, Jakarta

Kotler, Philip dan Kevin Lane Keller, (2008). Manajemen Pemasaran, Jilid 1, Penerbit Erlangga. Jakarta

Kriyantono, Rahmat. (2006). Teknik Praktis Riset Komunikasi. Jakarta: PT. Kencana Perdana.

McQuail, D. (2011). Teori Komunikasi Massa. McQuail. Jakarta: Salemba Humanica

Moleong, Lexy. (2006). Metodolgi Penelitian Kualitatif. Jakarta: PT. Remaja Rosdakarya

Siregar, Syofian. (2013). Metode Penelitian Kuantitatif Dilengkapi Perbandingan Perhitungan Manual \& SPSS, Edisi Pertama, Jakarta: Kencana

Sugiyono. (2006).Metode Penelitian Kuantitatif Kualitatif dan R\&D. Bandung Alfabeta.

Sugiyono.(2014). Metode Penelitian Pendidikan Pendekatan Kuantitatif,Kualitatif, dan $R \& D$. Bandung: Alfabeta. 